\title{
NUMERICAL INVESTIGATION OF ENERGY LOSSES IN THE ENVIRONMENT FOR MESOPHILIC MODE OF FERMENTATION
}

\author{
M. M. Zablodskiy, Doctor of Engineering, Professor \\ E-mail: zablodskiynn@gmail.com
}

M. O. Spodoba, post-graduate student

E-mail:spmisha@ukr.net

\section{National University of Life and Environmental Sciences of Ukraine}

\begin{abstract}
The article is devoted to the study of energy losses of a biogas reactor into the environment during the fermentation of biomass in the mesophilic temperature regime. The article considers the influence of the presence of the insulating layer of the biogas reactor and the ambient temperature on the amount of energy losses and the required energy to recover these losses depending on the volume of the biogas reactor. The developed mathematical model allows to estimate the intensity of energy losses to the environment taking into account the amount of contamination of the inner wall of the biogas reactor, ambient temperature, average wind speed for the reactor location, surface area of the biogas reactor and its volume, material from which the biogas reactor is made, insulating layer and its material, mode of movement and frequency of biomass mixing.

The following assumptions have been made for numerical studies: biomass fermentation takes place in the mesophilic temperature regime $T_{1}=35{ }^{\circ} \mathrm{C}$, biogas reactors with a volume of 50 to 200 liters, at ambient temperatures $T_{2}$ from -30 to $+30{ }^{\circ} \mathrm{C}$.

It has been established that the heat loss to the environment for different volumes of biogas reactors, regardless of the ambient temperature and the presence or absence of an insulating layer, is not linear.

Numerical research has shown that the use of an insulating layer of mineral wool with a thickness of $100 \mathrm{~mm}$, depending on the volume of the biogas reactor and ambient temperature, reduces the amount of energy required to maintain the thermal regime by 5563 times. Taking into account the amount of losses at the stage of design and manufacture of biogas reactors will reduce energy costs to maintain the required temperature, thereby increasing the profitability of the biogas plant.
\end{abstract}

Key words: heat loss, biogas plant, mesophilic regime, heat transfer, thermal resistance, energy efficiency

Introduction. Every year the amount of accumulated plant and animal waste increases, and the systems for their preservation are environmentally harmful due to the constant emissions of methane and nitric oxide into the air [1]. Because of this, the world's population is forced to look for alternative methods of disposing of accumulated organic 
waste. The most widespread for the utilization of organic waste were anaerobic treatment, which is carried out in special tanks with constant support of microclimate parameters biogas plants [2].

Analysis of recent research and publications. The productivity of a biogas plant is functionally dependent on the temperature regime of anaerobic fermentation. In $[3,4]$ it was found that a sharp decrease or sharp increase in temperature creates a disturbing effect on bacteria, which leads to a decrease in biogas yield. Therefore, temperature plays a major role in the quantity and quality of biogas produced from one kilogram of dry organic matter during the fermentation time in the biogas reactor. According to the conditions of the anaerobic fermentation process, biogas is released in three temperature modes [3-6]: psychrophilic $-15-20{ }^{\circ} \mathrm{C}$, mesophilic $-33-37{ }^{\circ} \mathrm{C}$, thermophilic $55-57^{\circ} \mathrm{C}$.

The mesophilic fermentation regime is characterized by the highest activity of methanogenic bacteria with the maximum formation of biogas at the fermentation temperature $35^{\circ} \mathrm{C}[2,5,7]$.

In [8], the authors analyzed the heat transfer from the substrate and biogas to the environment using Matlab software. In [9], scientists conducted energy modeling of an anaerobic reactor sunk into the ground, in order to obtain stable biogas production and maintain a constant fermentation temperature with lower energy costs.

In $[2,3-5,7,10,11]$ the issue of maintaining the required temperature in biogas reactors using different heating methods is considered. In $[2,4,5,7]$ the system of substrate heating in a biogas reactor by pumping heated water through heat exchangers is considered. Heated water is heated in boiler units with a part of the produced biogas, in the literature $[2,5]$ data on the consumption of biogas for heating water in the boiler room, approximately $30-40 \%$ of the total volume of biogas produced. In the literature [1] heat losses to the environment at three fermentation temperature regimes are considered: psychrophilic, mesophilic and thermophilic. Graphical dependences of change of heat losses at different ambient temperatures are given. However, the study did not take into account the speed of the mixing device and the magnitude of the increase in resistance due to the adhesion of the substrate on the inner wall of the biogas reactor. 
During anaerobic fermentation, the biogas reactor is located in the climatic zone of the environment, according to the law of thermal equilibrium, when two media with different temperatures come into contact, heat transfer occurs between them, as a result of which their temperature equalizes. Therefore, the determination of energy loss into environment in the mesophilic mode of fermentation at different temperatures in the environment is an actuality question.

Purpose. The aim of the article is to determine the energy loss to the environment during the mesophilic digestion mode for different volumes of biogas reactors at different ambient temperatures, taking into account deposits of biomass particles on the inner surface of the walls of the biogas reactor and speed of the mixing device.

Materials and methods. A biogas reactor is a multidimensional system with variable technological parameters over time that, require certain electrical, thermal and mechanical energy. The equation of heat balance is taken as a basis for determining heat consumption to maintain a constant temperature of anaerobic fermentation. With the known definition of the components, the heat balance equation takes into account: the heat of the available substrate in the biogas reactor $\left(Q_{s u b}\right)$, heat of fermentation $\left(Q_{f}\right)$, heat of the heating device $\left(Q_{\text {heat }}\right)$, into the environment $\left(Q_{e n}\right)$, heat loss with biogas $\left(Q_{b}\right)$ and waste sludge $\left(Q_{s}\right)$ [12].

$$
Q_{\text {sub }}+Q_{f}+Q_{\text {heat }}=Q_{e n}+Q_{b}+Q_{S}
$$

We propose to improve the method of determining heat consumption to maintain a constant fermentation temperature by introducing into the existing equation of heat balance (1), the value of thermal energy of fresh substrate $\left(Q_{f r . s u b}\right)$, which is loaded into the reactor and in the case of using an immersion electric biomass heater, in which excess thermal energy accumulates, add the value of heat obtained by cooling the heater structure $\left(Q_{c . h . d}\right)$. Then the improved heat balance equation for a biogas reactor will look like:

$$
Q_{s u b}+Q_{f}+Q_{\text {heat }}+Q_{c . h . d}+Q_{\text {fr.sub }}=Q_{e n}+Q_{b}+Q_{s}
$$

As in any technological process, the first goal is to create a well-established system with the lowest capital costs to minimize energy costs, biogas systems are no exception, 
the main requirement when designing biogas plants is to minimize energy costs to maintain the temperature of anaerobic fermentation, which should be close to zero:

$$
Q_{\text {heat }} \rightarrow 0,
$$

With regard to heat loss to the environment, it is also necessary to provide the following conditions for anaerobic fermentation, so that heat loss was minimal with minimal capital investment:

$$
Q_{e n} \rightarrow \min ,
$$

According to the above, the heat available in the substrate should be optimal for the intensive course of the anaerobic process. However, heat is constantly exchanged between the biogas reactor and the environment, heat is lost into the environment.

The magnitude of heat loss to the environment depends on many conditions:

$$
Q_{e n}=f\left(k, t_{s u b}, t_{e n}, \lambda_{s t}, \delta_{s t}, F, \tau, v_{a v}, \lambda_{i . m}, \delta_{i . m}, r_{o b t}\right)
$$

where $k$ - heat transfer coefficient, takes into account the average heat transfer rate over the entire heat transfer surface, $W /\left(m^{2} \cdot{ }^{\circ} \mathrm{C}\right) ; t_{\text {sub }}$ - fermentation temperature of the substrate, ${ }^{\circ} \mathrm{C} ; t_{\mathrm{en}}$ - ambient temperature, ${ }^{\circ} \mathrm{C} ; \lambda_{s t}$ - thermal conductivity of the wall of the biogas reactor, $W /\left(m \cdot{ }^{\circ} \mathrm{C}\right) ; \delta_{s t}-$ wall thickness of the biogas reactor, $\mathrm{m} ; F$ - surface area of the biogas reactor, $\mathrm{m}^{2} ; \tau$ - time, hour; $r_{o b t}$ - reducing the heat transfer coefficient when dirt sticks to the inner walls of the biogas reactor; $v_{a v}$-average wind speed, $v_{a v}=2 \mathrm{~m} / \mathrm{s}$; $\lambda_{i . m}$ - thermal conductivity of the insulating material, $W /\left(m \cdot{ }^{\circ} \mathrm{C}\right) ; \delta_{i . m}-$ thickness of the insulating material, $\mathrm{m}$.

Thus, the relationship between heat loss to the environment and the heat transfer surface is described by Newton-Richman's law [13]:

$$
Q_{\text {en }}=k \cdot F \cdot \tau \cdot\left(t_{\text {sub }}-t_{\text {en }}\right)
$$

In equation (6), the heat transfer coefficient $k$ depends on a large number of factors, so it is recommended to find it from the following equation $[13,14]$ :

$$
k=\frac{1}{\frac{1}{\alpha_{1}}+\frac{\delta_{s t}}{\lambda_{s t}}+\frac{\delta_{i . m}}{\lambda_{i . m}}+\frac{1}{\alpha_{2}}}
$$


where $\alpha_{1}$ - heat transfer coefficient from the substrate to the tank wall, $W /\left(m^{2} \cdot{ }^{\circ} \mathrm{C}\right) ; \alpha_{2}-$ heat transfer coefficient from the tank wall to the environment, $W /\left(\mathrm{m}^{2} \cdot{ }^{\circ} \mathrm{C}\right)$.

Contamination on the tank wall creates an additional barrier to heat transfer to the environment. This is a positive component, because lowering the temperature leads to a decrease in the intensity of methane formation, and the lost heat must be restored, which leads to higher energy costs and reduced profitability of the biogas plant. The magnitude of this resistance $r_{o b t}=0 \ldots 6,6 \cdot 10^{-4}\left(m^{2} \cdot{ }^{\circ} \mathrm{C}\right) / W[15,16]$, therefore, considering the pollution, the value of the heat transfer coefficient (7) is recommended to be calculated as follows:

$$
k=\frac{1}{\frac{1}{\alpha_{1}}+\frac{\delta_{s t}}{\lambda_{s t}}+r_{o b t}+\frac{\delta_{i . m}}{\lambda_{i . m}}+\frac{1}{\alpha_{2}}}
$$

The intensity of heat transfer from the substrate to the reactor wall $\alpha_{1}$, depends on the surface area of the reservoir, the speed of biomass, the mixing mode (laminar or turbulent) and the influence of the physical properties of the environment, which is found by the criterion of similarity of Prandtl. Therefore, the heat transfer coefficient from the substrate to the tank wall is determined by the formula $[15,16]$ :

$$
\alpha_{1}=1,01 \cdot \frac{\lambda}{d} \cdot\left(\operatorname{Re}_{\mathrm{m}}\right)^{0,62} \cdot(\operatorname{Pr})^{0,36} \cdot\left(\frac{\operatorname{Pr}_{\text {mid }}}{\operatorname{Pr}_{\text {wall }}}\right)^{0,25}
$$

where $d$ - inner diameter of the biogas reactor, $\mathrm{m}$; $\operatorname{Re}_{m}$ - modified Reynolds criterion; $\operatorname{Pr}_{\text {mid }}$ - criterion of Prandtl similarity in the middle of the reactor at fermentation temperature; $\mathrm{Pr}_{\text {wall }}$ - Prandtl similarity criterion at the temperature near the wall of the biogas reactor; $\operatorname{Pr}-$ Prandtl similarity criterion $[15,16] ; \lambda-$ the thermal conductivity of the substrate, $\lambda=0,62 \mathrm{~W} /\left(\mathrm{m} \cdot{ }^{\circ} \mathrm{C}\right)$.

The main purpose of hydrodynamics is to determine the mode of fluid motion, which is estimated on the basis of a dimensionless modified Reynolds criterion for mixing $[3,5$, 15]:

$$
\operatorname{Re}_{m}=\frac{\rho \cdot n \cdot d_{m}^{2}}{\mu}
$$


where $\rho$-substrate density, $\mathrm{kg} / \mathrm{m}^{3} ; n$ - stirrer speed, $\mathrm{rpm} ; d_{\mathrm{m}}$ - diameter of the mixer, $\mathrm{m}$.

$$
\operatorname{Pr}=\frac{c \cdot \mu}{\lambda}
$$

where $\mu$-dynamic viscosity of the substrate, $\mu=0,048 P a \cdot s$ [17]; $c-$ specific heat of the substrate, $c=4200 \mathrm{~J} /\left(\mathrm{kg} \cdot{ }^{\circ} \mathrm{C}\right)[17]$.

The heat transfer coefficient from the tank wall to the environment is determined by the formula $[14,17]$ :

$$
\alpha_{2}=11,6+7 \cdot \sqrt{v_{a v}}
$$

The heat transfer area of the biogas reactor surface consists of the side surface area $\left(F_{\text {wall }}\right)$ and the area of the upper part of the bioreactor is made in the form of a hemisphere $\left(F_{h . s p}\right)$, which are determined from the equations:

The area of the side surface of the cylinder [14]:

$$
F_{\text {wall }}=2 \cdot \pi \cdot H \cdot R
$$

The area of the dome is made of a hemisphere [14]:

$$
F_{h . s p}=2 \cdot \pi \cdot R^{2}
$$

The total surface area of the biogas reactor:

$$
F=F_{\text {wall }}+F_{h . s p}
$$

where $H$ - height of the biogas reactor, $\mathrm{m} ; R$ - radius of the biogas reactor, $\mathrm{m}$.

Results and discussion. In order to determine the power required to cover heat loss to the environment for the mesophilic regime of anaerobic fermentation at different ambient temperatures, theoretical studies were performed according to formula (6).

The following initial conditions were set for the research: fermentation takes place in the mesophilic mode $T_{1}=35{ }^{\circ} \mathrm{C}$; the biogas reactor is made of steel; reactors volume $V$, from 50 to 200 liters; ambient temperature $T_{2}$ from -30 to $+30{ }^{\circ} \mathrm{C}$; reactors height $H$, from 0,6 to $0,88 \mathrm{~m}$; radius of reactors $R$, from 0,18 to $0,28 \mathrm{~m}$. The research, were performed for an insulated tank and without insulation. The results are shown in Fig. 1-2. 


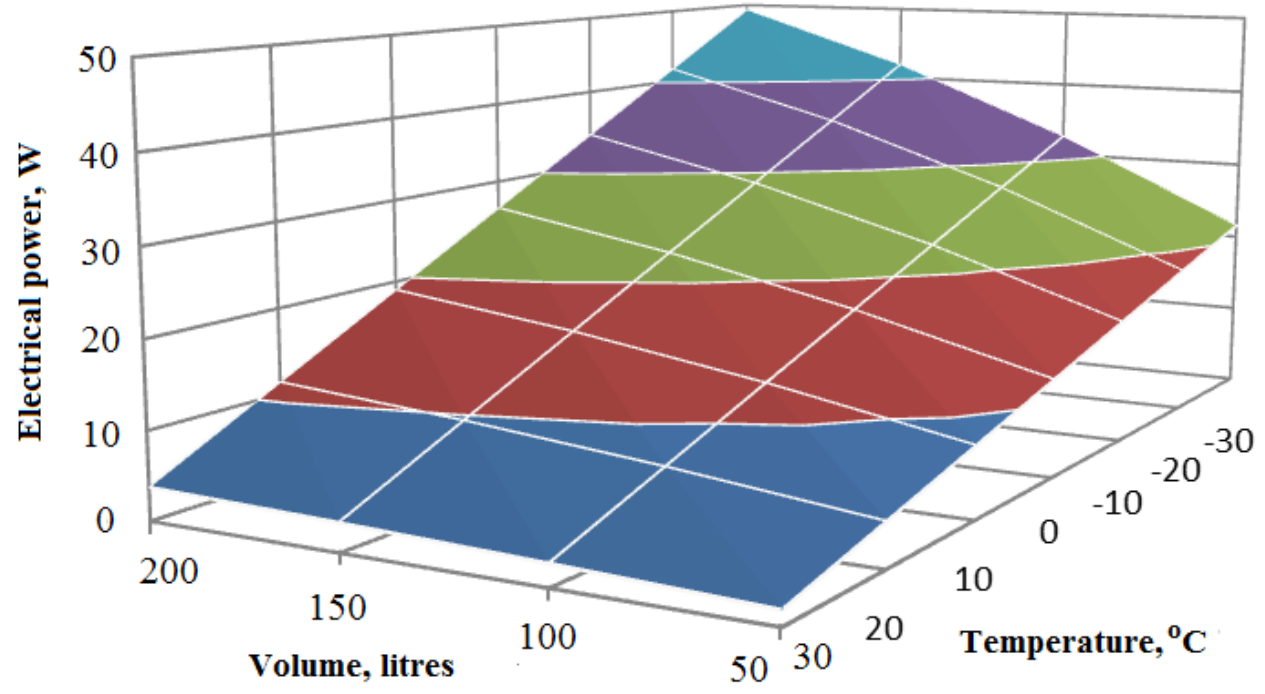

Fig. 1. Power consumption to cover heat loss to the environment in the mesophilic mode of fermentation, at different ambient temperatures and reactor insulated with mineral wool thickness of $100 \mathrm{~mm}$

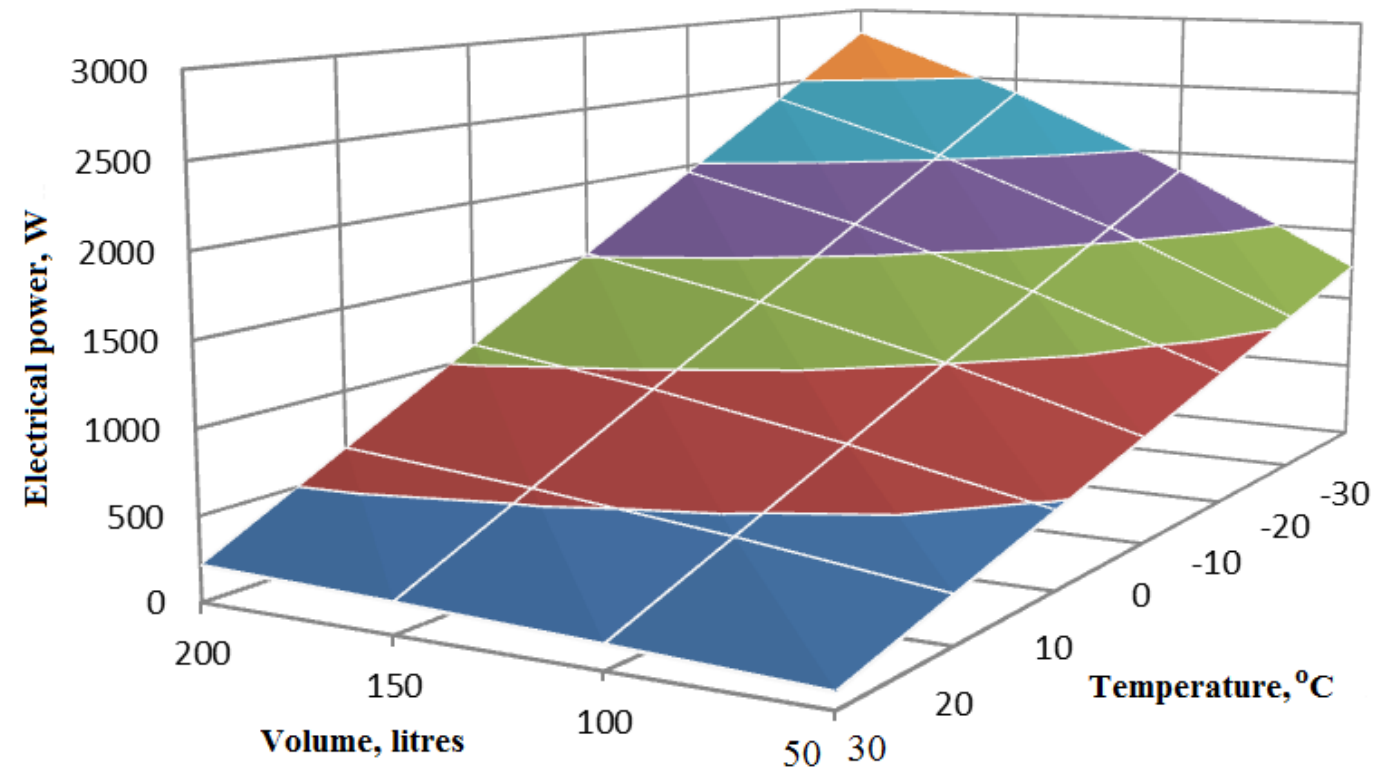

Fig. 2. Power consumption to cover heat loss to the environment in the mesophilic mode of fermentation, at different ambient temperatures in the absence of reactor insulation

Analyzing the dependence of power consumption to cover heat loss to the environment presented in (Fig.1) found that with increasing ambient temperature $T_{2}$, losses are reduced. This is due to the conditions of establishing temperature equilibrium 
between substrate temperatures $T_{1}$, in the biogas reactor and the environment. However, purple and blue indicate areas with increased heat loss from the biogas reactor to the environment at temperatures below $\left(-20{ }^{\circ} \mathrm{C}\right)$. For the considered volumes of biogas reactors at temperature $\left(-30{ }^{\circ} \mathrm{C}\right)$, power is from 22 to 49 watts, and at $+10{ }^{\circ} \mathrm{C}$, power required to cover heat loss is from 8 to 19 watts per hour.

Analysis of the dependence of power consumption to cover heat loss to the environment without insulation (Fig. 2), showed a significant increase in the required power with decreasing ambient temperature $\left(T_{2}\right)$. For the considered volumes of biogas reactors at temperature $\left(-30{ }^{\circ} \mathrm{C}\right)$, power is from 1232 to 2822 watts, and at $+10{ }^{\circ} \mathrm{C}$ power required to cover heat loss is from 474 to 1085 watts per hour.

As shown in Fig. 1 and 2 with decreasing temperature below $-20{ }^{\circ} \mathrm{C}, 150$ and 200 liter biogas reactors have a significant increase in heat loss, which are marked in purple, blue and orange. This is explained by the following: with a larger volume in the biogas reactor, more thermal energy accumulates; a larger volume of biomass requires a larger tank, thus increasing the area of contact with the environment.

In $[11,18]$, scientists conducted theoretical studies on the possibility of using largevolume biogas reactors deep into the ground, in order to reduce energy costs to maintain a stable temperature of anaerobic fermentation.

The results shown in Fig. 1 and 2 confirm the reduction of heat loss depending on the volume of the biogas reactor and the increase in the ambient temperature.

After analyzing the obtained graphical dependences, we can conclude that, depending on the climatic zone of the biogas reactor, it is necessary to insulate the latter in order to reduce energy costs to cover heat loss to environment. Also, in cold and temperate climates, in order to reduce the contact between the biogas reactor and the environment, it is advisable to install large tanks deep into the ground, while increasing the cost of construction of such a reactor, but heat loss during anaerobic fermentation is relatively lower than in tanks placed in the open air, as evidenced by the results shown in Fig.1, 2 and in $[9,11,18]$. 
Taking into account the above results, the method proposed in the article to determine heat loss to the environment can be used in theoretical calculations and studies of thermal processes in biogas reactors.

Conclusions. The obtained graphical dependences of heat losses in the environment at the mesophilic mode of fermentation at different ambient temperatures indicate that depending on the volume of the biogas reactor and the absence of an insulating layer, at temperatures below 0 heat losses can reach values that adversely affect on to heat balance of the anaerobic process. The significant influence of insulating structures on the amount of heat loss in biogas reactors at different ambient temperatures is determined.

Taking into account the amount of losses in biogas reactors will reduce energy costs for maintaining a constant temperature and increase the productivity of the biogas plant.

Analyzing the graphical dependences (Fig. 2.1 and Fig. 2.2), it was found that heat loss to the environment for different volumes of biogas reactors, regardless of ambient temperature and the presence or absence of an insulating layer is not linear.

The used mathematical model allowed to obtain the values of heat losses of biogas reactors depending on the ambient temperature, the amount of contamination of the inner walls of the tank, reactor volume, the presence of an insulating layer and its absence, based on, concludes that insulation of biogas reactors reduces energy to restore heat loss to the environment in $55-63$ times, thereby increasing the profitability of the biogas plant.

\section{References}

1. Bereznitskaya, M. V., Butrim, O. V., Panchenko, G. G. (2008). National inventory of anthropogenic emissions from sources and removals by sinks of greenhouse gases in Ukraine for 1990-2007. Kyiv, Ukraine: Ministry of Environmental Protection of Ukraine, 319.

2. Baader, V., Donet, E., Brennderfer M. (1982). Biogas. Theory and practice. 148.

3. Pham, C. H., Vu, C. C., Sommer, S. G., Bruun, S. (2014) Factors Affecting Process Temperature and Biogas Production in Small-scale Rural Biogas Digesters in Winter in Northern Vietnam. 27 (7), 1050-1056.

4. Deublein, D., Steinhauser, A. (2008). Biogas from Waste and Renewable Resources. An Introduction. Weinheim: WILEY-VCH Verlag GmbH \& Co, 450.

5. Ratushnyak, G. S., Dzhedzhula, V. V., Anokhin, K. V. (2010). Energy-saving renewable heat sources. Vinnitsa: VNTU, 170.

6. Barbara, E., Heinz S. (2011). Biogas plants. Practical guide. Zorg Biogas, 268. 
7. Druzyanova, V. P., Kobyakova, E. N. (2016). Investigation of biogas output at different mesophilic regime temperatures in small volume biogas plants. Bulletin of the East Siberian State University of Technology and Management Ulan-Ude, 3 (60), 5-13.

8. Shaheen, M., Nene, A. A. (2014). Thermal simulation of biogas plants using Matlab. International Journal of Engineering Research and Applications, 4, 24-28.

9. Terradas, G., Triolo, J. M., Pham, C. H., Marti- Herrero, J., Sommer, S. G. (2014). Thermic model to predict biogas production in unheated fixed dome digesters buried in the ground. Environmental Science and Technology, 48, 3253-3262.

10. Sadchikov, A. V., Kokarev, N. F. (2016). Optimization of the thermal regime in biogas plants. Fundamental research, 2 (1), 90-93.

11. Teleszewski, T. J., Zukowski, M. (2018). Analysis of Heat Loss of a Biogas Anaerobic Digester in Weather Conditions in Poland. Journal of Ecological Engineering, 19(4), 242-250.

12. Zablodskiy, M.M., Spodoba, M.O. (2020). Improvement of the method for determining energy consumption in a biogas reactor. XII International Conference "Electronic Processes in Organic and Inorganic Materials" ICEPOM-12, (June 01-05, 2020), 311.

13. Lobasova, M. S., Finnikov, K. A., Milovidova, T. A. (2009). Heat and mass transfer. 295.

14. Gilchuk, V. V., Khalatov A. A. (2017). The theory of thermal conductivity. 86.

15. Khusnutdinov, I. Sh., Zabbarov, R. R., Khanova, A. G., Nikolaev, V. F., Skvortsova, G. Sh. (2012). Technologies for processing highly stable water-hydrocarbon emulsions: monograph, 180.

16. Pavlov, K. F. (1987). Examples and tasks on the course of processes and apparatuses of chemical technology. 576.

17. Yurkova, V. V., Shklyar, V. I., Dubrovskaya V. V. (2014). Analysis of energy efficiency of cogeneration plants using biofuels. Scientific journal of the Kyiv Polytechnic University. Igor Sikorsky "Energy, Economics, Technologies, Ecology", (3), 29-32.

18. Ishchenko, K., Denesiak, D. (2018). Energy efficiency of anaerobic bioreactors with different temporary technological process. Bulletin of Mykhailo Ostrohradskyi: KrNU, 3, 14-19.

\section{ЧИСЕЛЬНЕ ДОСЛІДЖЕННЯ ЕНЕРГЕТИЧНИХ ВТРАТ У НАВКОЛИШНС СЕРЕДОВИЩЕ ДЛЯ МЕЗОФІЛЬНОГО РЕЖИМУ ЗБРОДЖУВАННЯ \\ М. М. Заблодський, М. О. Сподоба}

Анотація. Стаття присвячена питанню дослідження енергетичних втрат біогазового реактора у навколишне середовище при зброджуванні біомаси у мезофільному температурному режимі. Розглянуто вилив наявності утеплюючого шару біогазового реактора та температури навколишнього середовища на величину енергетичних втрат та необхідної енергї на відновлення цих втрат в залежності від об'єму біогазового реактора. Розроблена математична модель дозволяє очінити інтенсивність енергетичних втрат до навколишнього середовища, враховуючи величину забруднення внутрішньої стінки біогазового 
реактора, температуру навколишнього середовищу, середню ивидкість вітру для місия розташування реактора, площу поверхні біогазового реактора та його об' $\epsilon м$, матеріал з якого виконано біогазовий реактор, товщину утеплюючого шару та його матеріал, режим руху та частоту перемішування біомаси.

Для чисельних досліджень було прийнято такі припущення: зброджування біомаси відбувається у мезофільному температурному режимі $T_{1}=35^{\circ} \mathrm{C}$, біогазові реактори об'ємом від 50 до 200 літрів, при температурі навколишнього середовищза $T_{2}$ від -30 до $+30{ }^{\circ} \mathrm{C}$.

Встановлено, щуо втрати тепла в навколишнє середовище для різних обсягів біогазових реакторів, незалежно від температури навколишнього середовища та наявності або відсутності ізолюючого шару, є не лінійними.

Чисельні дослідження показали, щуо використання ізолюючого шару мінеральної вати товщиною 100 мм, залежно від об 'єму біогазового реактора та температури навколишнього середовища, зменшує кількість енергї̈, необхідної для підтримання теплового режиму, в $55-63$ рази. Врахування величини втрат на стадіi проектування та виготовлення біогазових реакторів зменшить енергетичні витрати на підтримку необхідної температури, збільшуючи тим самим прибутковість біогазової установки.

Ключові слова: теплові втрати, біогазова установка, мезофільний режим, теплопередача, термічний опір, енергетична ефективність

\section{ЧИСЛОВЫЕ ИССЛЕДОВАНИЯ ЭНЕРГЕТИЧЕСКИХ ПОТЕРЬ В ОКРУЖАЮЩУЮ СРЕДУ ДЛЯ МЕЗОФИЛЬНОГО РЕЖИМА СБРАЖИВАНИЯ}

\section{Н. Н. Заблодский, М. А. Сподоба}

Аннотация. Статья посвящена вопросу исследования энергетических потерь биогазового реактора в окружающую среду при сбраживании биомассы в мезофильном температурном режиме. Рассмотрено влияние наличия утепляющего слоя биогазового реактора и температуры окружающей среды на величину энергетических потерь и необходимой энергии на восстановление этих потерь в зависимости от объема биогазового реактора. Разработанная математическая модель позволяет оценить интенсивность энергетических потерь в окружаюшую среду, учитывая величину загрязнения внутренней стенки биогазового реактора, температуру окружающей среды, среднюю скорость ветра для местоположения реактора, площуадь поверхности биогазового реактора и его объем, материал из которого выполнен биогазовый реактор, толщуину утепляющего слоя и его материал, режим движения и частоту перемешивания биомассы.

Для числовых исследований было принято следующче допущฺения: сбраживание биомассы происходит в мезофильном температурном режиме $T_{1}=35^{\circ} \mathrm{C}$, биогазовые реакторы объемом от 50 к 200 литров, при температуре окружающей среды $T_{2}$ om -30 до $+30{ }^{\circ} \mathrm{C}$.

Установлено, что потери тепла в окружаюшую среду для различных объемов биогазовых реакторов, независимо от температуры окружающей среды и наличия или отсутствия изолирующего слоя, являются не линейныли. 
Числовые исследования показали, что использование изолирующего слоя минеральной ваты толщиной 100 мм, в зависимости от объема биогазового реактора и температуры окружающей среды, уменьшает количество энергии, необходимой для поддержания теплового режима в 55-63 раза. Учет величины потерь на стадии проектирования и изготовления биогазовых реакторов уменьшит энергетические затраты на поддержание необходимой температуры, увеличивая тем самым доходность биогазовой установки.

Ключевые слова: тепловые потери, биогазовая установка, мезофильный режим, теплопередача, термическое сопротивление, энергетическая эффективность 